\title{
THE PEA MOSAIC VIRUS AT THE EXPERIMENTAL FARMS, VIIK AND MUDDUSNIEMI
}

\author{
KyöSti RaININKo \\ Department of Plant Pathology, University of Helsinki
}

Received May 13, 1964

The occurrence of virus diseases on red clover and their causal agents in Finland have only in recent years been investigated. Recently TAPIO (15) has published the first reports on the appearance of pea mosaic and bean yellow mosaic virus in red clover. There are several aphid species in Finland known to be able to transmit virus diseases of legumes (7). TAPIO (15) found that at least the Acyrthosiphon pisum HARris, Aphis fabae ScOp. and probably the Megoura viciae BUcKT. are vectors of pea mosaic and bean yellow mosaic virus in Finland.

In the summer of 1960 at the Viik Experimental Farm, symptoms were observed in red clover which suggested the presence of virus diseases. The first observations were made on experimental plots, but since the disease appeared to occur elsewhere, too, observations were made also on the ordinary fields of the farm. The observations were continued in 1961 and 1962; in these years virus symptoms occurred also in peas. The occurrence of the virus was also investigated at the Muddusniemi Experimental Farm in Lapland $\left(69^{\circ} 5^{\prime} \mathrm{N}\right)$.

The symptoms of this disease varied greatly in red clover (Fig. 1). The most common symptom was mottling of the leaves, in which the chlorophyll appeared as dark-coloured blotches distinct from the lighter surrounding colour. In some places the chlorotic areas formed striations parallel to the leaf veins. These striations were light green, yellowish green or sometimes yellow. A yellow colour also appeared often in the form of small spots which were elongated and parallel to the leaf veins. The leaves in general were of normal shape and size, although occasionally small and 


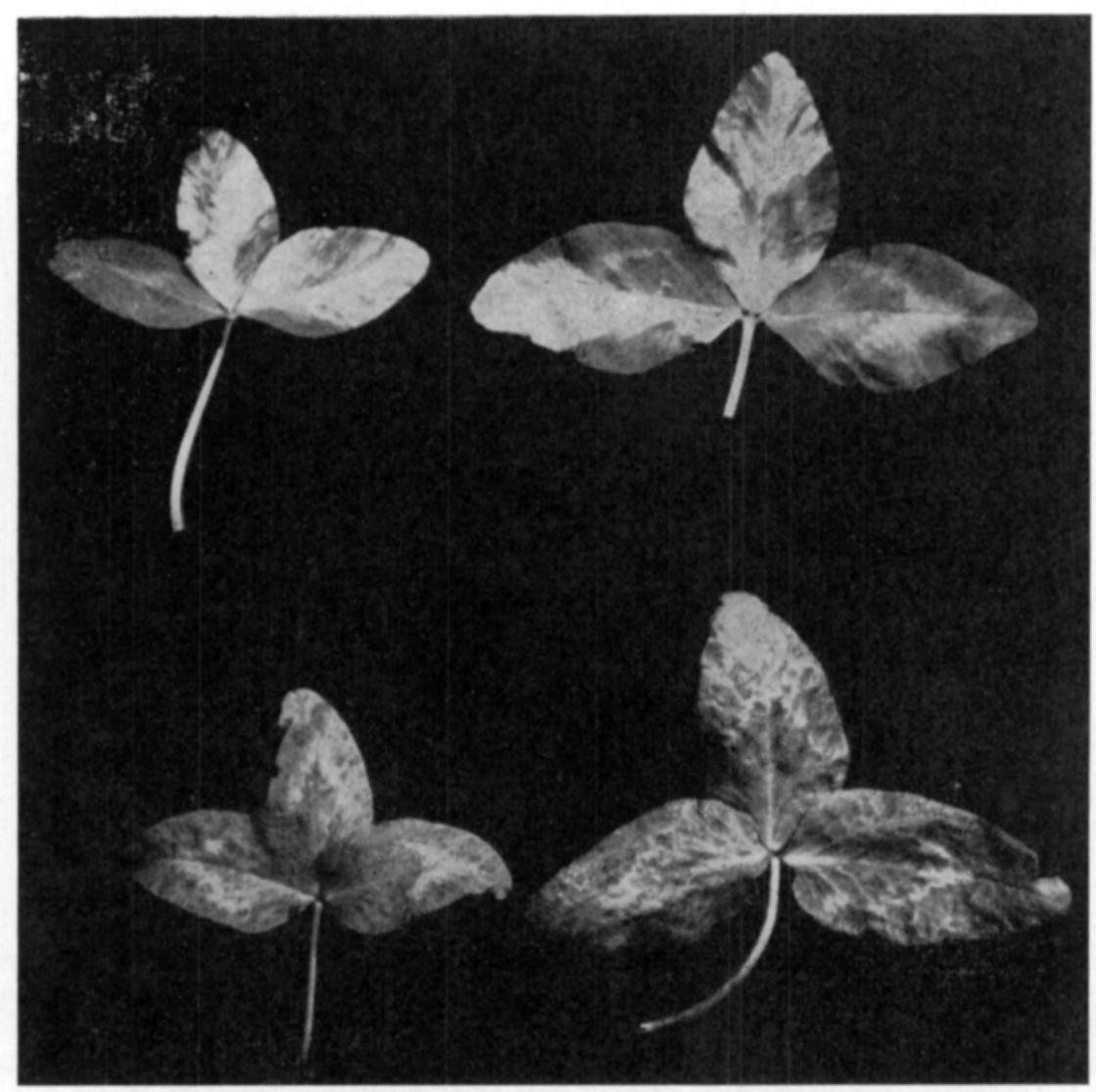

Fig. 1. Symptoms of pea mosaic virus on red clover.

wrinkled. The infected plants were often smaller than the healthy plants, but sometimes as large as the latter.

In the leaves of the pea plants, localized chlorosis appeared which was clearly distinct from the dark green surrounding colour (Fig. 2). The spots were almost completely yellow. Similar chlorosis occurred in the stipules and sometimes also in the youngest parts of the shoots. The growth of the plant did not appear to be hindered by the disease.

\section{Virus testing}

The causal agent of the disease was studied by transmission tests. In order to prevent the virus-transmitting insects from coming in to contact with the test plants, these were grown in isolation cages with dimensions of $60 \times 60 \times 60 \mathrm{~cm}$. The top and two sides of the cages were made of glass, while the remaining two sides were made of gauze for ventilation. As a safety precaution, the plants were sprayed with insecticide (metasystoxin) at intervals of two weeks. 


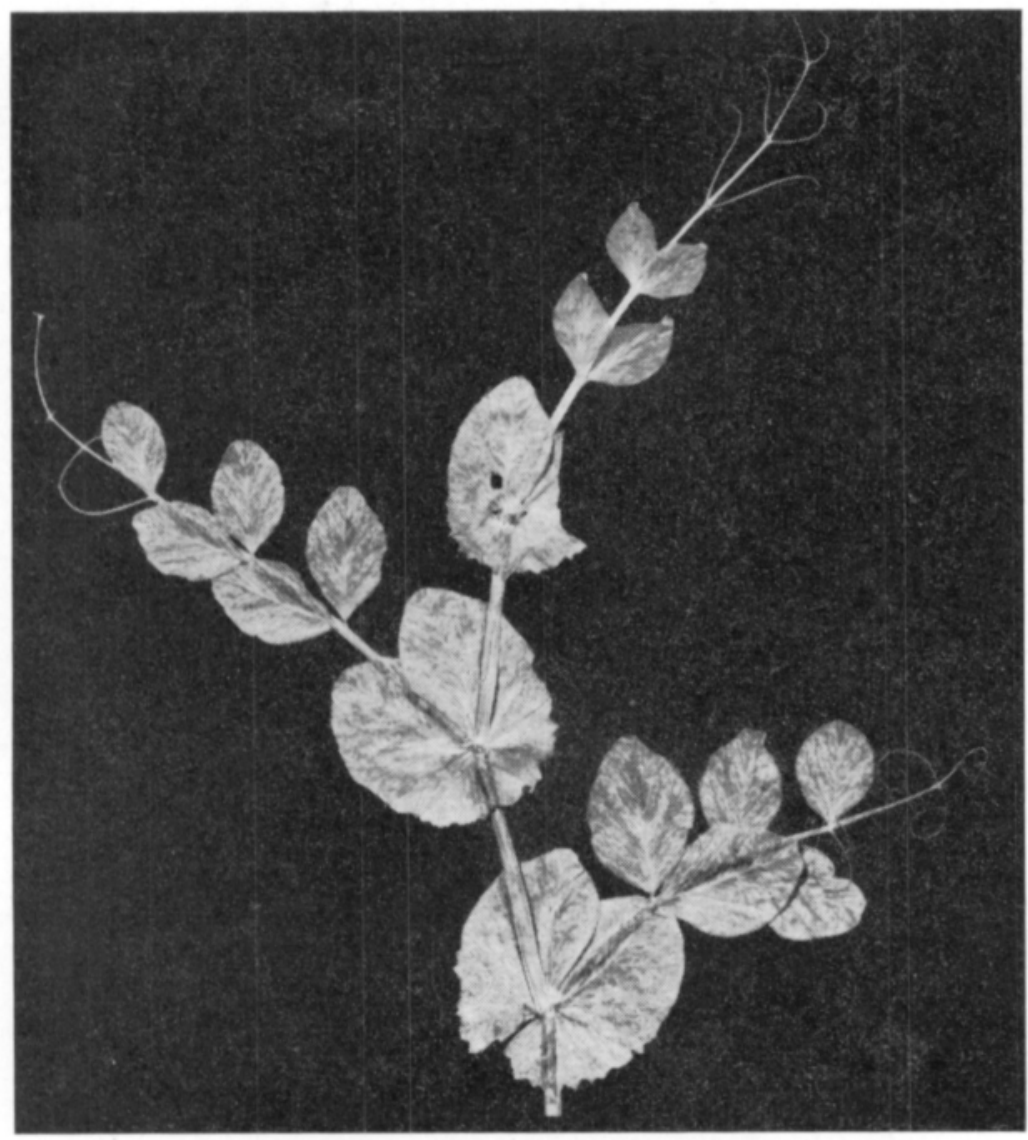

Fig. 2. Symptoms of pea mosaic on pea.

Inoculations were performed by mechanical applications of sap from infected plant to the leaf of the healthy plant, upon whose surface carborundum powder had been sprinkled; application was made by means of a glass rod, the finger, or the leaf of an infected plant. In most cases potassium phosphate or sodium sulphate solution was used as buffer.

The sap used as inoculum was obtained from infected pea or clover plants growing in the field. The sap from both pea and clover caused similar symptoms when inoculated into the same species of test plant (Table 1). Although the virus symptoms of the clover plants from which the sap inoculum was obtained were very variable, the symptoms appearing in the test plants were identical.

When mechanically inoculated, the virus caused a systemic infection in red clover, pea, broad bean, white sweetclover, yellow sweetclover and localized necrosis in Chenopodium quinoa. The common bean and soybean, on the contrary, was not infected by the virus. 
Table 1. Inoculations to test plants

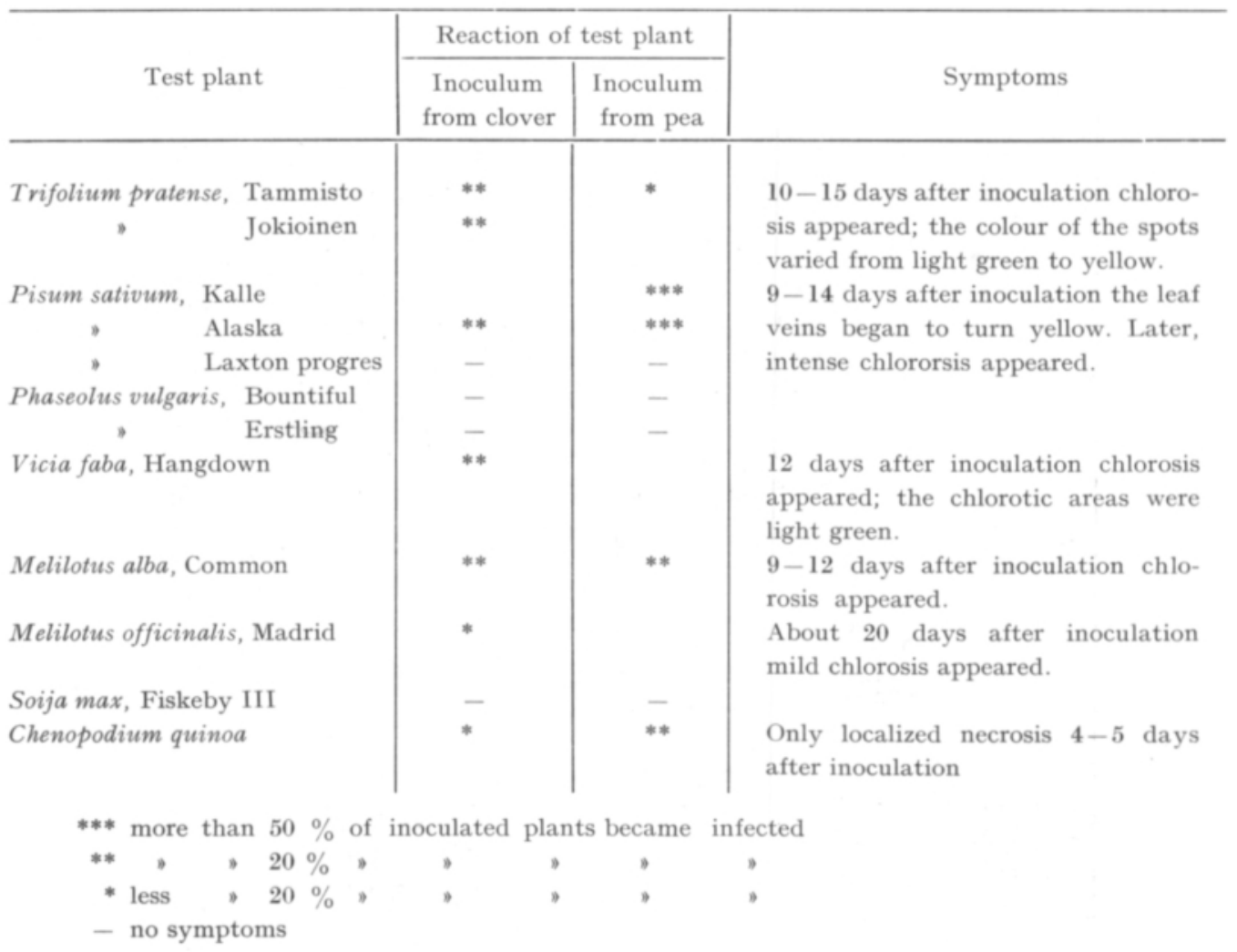

\section{The effect of the virus on the growth and overwintering of red clover}

According to observations made in the field, at least half of the clover plants showing virus symptoms were more or less stunted. In the greenhouse the virotic clover plants grew very poorly. The average weight of healthy plants, two months old, was approximately twice that of infected plants which had been inoculated at the age of three weeks:

$$
\text { No. of plants Aver. fresh weight, } g
$$

$\begin{array}{lrr}\text { Healthy } & 30 & 10.5 \\ \text { Infected } & 9 & 5.6\end{array}$

Observations on the overwintering of virotic clover plants were made in a trial in which both healthy plants (120 in number) and virotic plants (30) were transplanted in an outdoor trial plot in the spring of 1960. During the following winter 21 of the virotic plants $(70 \%)$ died, while only $10 \%$ of the healthy plants succumbed. In a large red clover breeding material consisting of about 2000 plants located on the same trial field, $12 \%$ died during the winter 1960-1961. During the same period 25 out of 52 virotic appearing plants in the same material died (nearly $50 \%$ ). 


\section{Frequency of the virus}

In the summer of 1960 the frequency of red clover virus in different parts of the Viik Experimental Farm was visually estimated on the basis of the symptoms in the plants. The method used was to count the number of virotic plants on each of the 30 test plots, generally $20 \mathrm{~m}^{2}$ in size. In June there were on an average 1.2 infected plants per $10 \mathrm{~m}^{2}$ in first-years leys and 2.2 in second-year leys, or 0.06 and $0.12 \%$ of the clover plants, respectively. In September a second count showed 3.0 infected plants per $10 \mathrm{~m}^{2}$ in first-year and 4.0 in second-year leys, or 0.20 and $0.25 \%$. The virus was considerably more abundant in the trial fields than in the ordinary fields of the farm (cf. 15). For example, in June $19600.1 \%$ of the clover plants in the trial plots showed virus symptoms and in September the figure was $0.5 \%$. The virus spread particularly heavily in the red clover spaced plant trials, in which as many as half of the plants in the most infected areas were virotic. In one greenhouse where an abundance of pea aphids (Acyrthosiphon pisum HARRIS) appeared, nearly all the clover plants were infected by the pea mosaic virus.

Observations made at the Muddusniemi Experimental Farm at Inari showed a certain extent of virus occurrence with an average of $0.25 \%$ of the clover plants being virotic.

The occurrence of the virus in different varieties of red clover was studied at Viik in the summer of 1960 by counting the numbers of virotic plants in the red clover variety trials (Table 2). The highest numbers of virotic plants were found in Tepa (Jo TPA 1) and in Jokioinen red clover (Jo 37). Practically no virus appeared in the three clovers imported from the Soviet Union: Permian, Siberian and Russian.

\section{Discussion}

The mosaic virus appearing in red clover and pea at Viik is caused by the pea

Table 2. The numbers of virotic clover plants in first-year red clover stands, summer 1960. The figures are averages from 5 replicates.

\begin{tabular}{|c|c|c|c|c|c|c|c|c|c|c|c|c|}
\hline Variety or strain & 尊 & 鸢 & 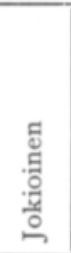 & 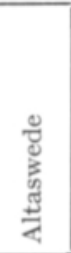 & 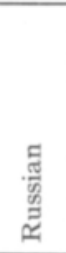 & 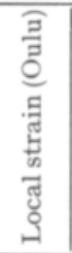 & 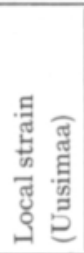 & 营 & 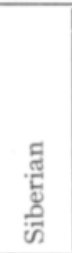 & 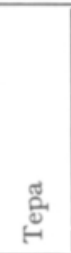 & 品 & $\chi^{2}$ \\
\hline $\begin{array}{l}\text { No. of infected } \\
\text { plants per } 100 \mathrm{~m}^{2} \\
\% \text { of plants } \\
\text { infected }\end{array}$ & $\begin{array}{r}18 \\
0.05\end{array}$ & $\begin{array}{r}58 \\
0.11\end{array}$ & $\begin{array}{r}98 \\
0.27\end{array}$ & $\begin{array}{r}32 \\
0.09\end{array}$ & $\begin{array}{r}14 \\
0.04\end{array}$ & 42 & $\begin{array}{r}14 \\
0.04\end{array}$ & 0.02 & 0.03 & $\begin{array}{r}104 \\
0.39\end{array}$ & $\begin{array}{r}44 \\
0.12\end{array}$ & $153.1^{* * *}$ \\
\hline
\end{tabular}

mosaic virus. In natural conditions this virus has been encountered both in pea $(1,15)$ and red clover $(12,15)$ in which it produced the same kind of symptoms as 
occurred in the infected plants at Viik. Also the test results (Table 1) agree with those presented in the literature on this virus $(5,13,14)$. The bean yellow mosaic virus, white clover mosaic virus, alsike clover mosaic virus, lupine mosaic virus and alfalfa mosaic virus cause the same kind of symptoms in red clover as does the pea mosaic virus. All of these viruses, excluding the latter, however, cause a systemic infection also in the bean. The alfalfa mosaic virus, on the other hand, produced localized necrosis in the bean and a systemic infection in Chenopodium quinoa $(6,13,14)$. The virus found at Viik caused no symptoms at all in the bean and in soybean, while in Chenopodium quinoa localized necrosis appeared (Table 1). The clover vein mosaic and the pea streak do not infect the bean. These viruses differ considerably from the pea mosaic virus even in regard to their symptoms. The clover vein mosaic does not cause any injury to Chenopodium quinoa. The pea streak, on other hand, produces a systemic infection also in the soybean $(4,9)$. Other viruses found in red clover differ even more - both in their symptoms and in their host plants - from the virus encountered at Viik $(6,13,14)$.

The pea mosaic virus occurring at the Viik Experimental Farm considerably weakened the growth and overwintering of red clover. There was, however, so little virus on the ordinary leys of the farm that the damage it caused was of no economic significance. The poor overwintering of virotic clover plants that have been found in North America, too (10), was evidently one reason why there was not more virus in second-year than in first-year leys. On the other hand, in regions where the winter is mild, old leys may be very badly infected by virus $(2,6)$. Besides it seemed at Viik that whenever an abundance of aphids appeared a relatively large part of the plants were diseased. The virus occurs most abundantly along the edges of roadways and on trampled leys, where it has better possibilities of being carried (3). In the trial fields at Viik, this virus has proved especially injurious in spaced plant trials, where it is necessary to handle the plants many times. Also in Germany NeItzeL (8) found that the pea mosaic virus spread rapidly in transplanted plots of clover.

There are considerable differences in virus disease resistance among pea and bean varieties (11). No data have appeared in the literature on similar differences between the red clover varieties. VALLE (16) states that the tetraploid variety Tepa was badly infected by virus in California, whereas the diploid Tammisto, from which Tepa was derived, was not infected. At Viik there was more virus in Tepa than in the other varieties tested. Virus was also abundant in the diploid variety Jokioinen.

\section{$S u m m$ ary}

A virus disease occurring in red clover and pea at the Viik Experimental Farm was found by means of plant inoculation tests to be caused by the pea mosaic virus. Infected plants grew slowly and overwintered poorly. There were variations in the frequency of the diseased plants in different red clover varieties. 


\section{LITERATURE}

(1) Doolitle, S. P. \& Jones, F. R. 1925. The mosaic disease in garden pea and other legumes. Phytopath. 15: $763-772$.

(2) FRY, P. R. 1959. A clover mosaic virus in New Zealand pastures. N. Z. J. Agric. Res. 2: $971-981$.

(3) Graves, C. H. Jr. \& Hagedorn, D. J. 1956. The red clover mosaic virus in Wisconsin. Phytopath. 46: $257-260$.

(4) Hagedorn D. J. \& Walker, J. C. 1949. Wisconsin pea streak. Ibid. 39: 837-847.

(5) - - 1954. Virus diseases of canning peas in Wisconsin. Univ. Wis. Res. Bull. 185: $1-32$.

(6) Hanson, E. W. \& Hagedorn, D. J. 1961. Viruses in red clover in Wisconsin. Agron. J. 53: $63-67$.

(7) Heıкınнeimo, O. 1959. Kasviviruksia siirrostavien lehtikirvojen esiintymisestä maassamme. Valt. maatal.koetoim. julk. 178: $20-40$.

(8) NeitzeL, K. 1961. Uber eine Viruskrankheit an Rot- und Schwedenklee und ihre Bedeutung für Züchtung und Anbau. Züchter 31: 94-98.

(9) Osborn, H. T. 1937. Vein mosaic of red clover. Phytopath. 27: 1051-1058.

(10) Oshima, N. \& Kernkamp, M. F. 1957. Effects of viruses on overwintering of red clover in Minnesota. Pl. Dis. Rep. 41: 10.

(11) Pierce, W. H. 1934. Viroses of the bean. Phytopath. 24: 87-115.

(12) --1937 . Legume viruses in Idaho. Ibid. 27: 836-843.

(13) Quantz, L. 1958a. Die Virosen der Leguminosen. Pflanzliche Virologie 2: 44-74.

(14) - - 1958b. Ein Beitrag zur Kenntnis der Erbsenvirosen in Deutschland. Nachr. bl. Deut. Pfl.schutzdienstes 10: $65-69$.

(15) TAPIo, E. 1964. Palkokasvien virustaudeista. Summary: Virus diseases on leguminous plants. Maatal. ja koetoim. 18: 202-211.

(16) VAlLE, O. 1960. Kokemuksia pohjois-eurooppalaisten nurmikasvijalosteiden siementuotannosta Pohjois-Amerikan mantereella. Suomen laiduntalous 32: 32-39.

\section{SELOSTUS:}

\section{HERNEEN KIRJOVIRUS HELSINGIN YLIOPISTON KOETILOILLA VIIKISSÄ JA MUDDUS- NIEMESSÄ}

\section{Kyösti RaININKo}

Helsingin yliopiston kasvipatologian laitos

Viikin ja Muddusniemen koetiloilla on puna-apilassa ja herneessä esiintynyt viroosia, joka testikasveja käyttäen on todettu herneen kirjoviruksen aiheuttamaksi. Sairaat apilat kasvoivat hitaasti ja talvehtivat heikosti. Viroosin yleisyys eri apilalajikkeissa vaihteli melkoisesti. Viroosia esiintyi kuitenkin varsinaisissa peltonurmissa siksi vähän, ettei sen aiheuttamilla vahingoilla ollut mitään taloudellista merkitystä. 